\title{
The Influence of Public Servants' Perceived Formalism and Organizational Environmental Strategy on Green Behavior in the Workplace
}

\author{
Hsiang-Te Liu (D)
}

check for

updates

Citation: Liu, H.-T. The Influence of Public Servants' Perceived Formalism and Organizational Environmental Strategy on Green Behavior in the Workplace. Sustainability 2021, 13, 11020. https://doi.org/10.3390/ su131911020

Academic Editors: Alessandro M. Peluso, Ermanno C. Tortia and Antonis A. Zorpas

Received: 31 July 2021

Accepted: 1 October 2021

Published: 4 October 2021

Publisher's Note: MDPI stays neutral with regard to jurisdictional claims in published maps and institutional affiliations.

Copyright: (C) 2021 by the author. Licensee MDPI, Basel, Switzerland. This article is an open access article distributed under the terms and conditions of the Creative Commons Attribution (CC BY) license (https:/ / creativecommons.org/licenses/by/ $4.0 /)$.
Department of Public Affairs, Ming Chuan University, Taoyuan 333, Taiwan; lback@mail.mcu.edu.tw

\begin{abstract}
This study explored the influence of public servants' green attitude, green behavior intention, organization environmental strategy, green lifestyle, and formalism on green behavior. For Taiwan's government agencies, environmental protection and sustainable development issues must be inculcated into government organizations and deeply ingrained into the mindset of civil servants. In particular, this research incorporates the concept of 'formalism' proposed by Riggs in administrative ecology. Exploration of the influence of civil servants' cognition of formalism on green behavior has not been explored in any previous studies. This study collected 308 valid public servants who worked in the public sector in Taiwan and used Lisrel and SEM to justify the hypotheses explored. The results showed that civil servants' green attitude positively affected green intention, as well as the fact that green behavior intention, organization environmental strategy, and green lifestyle positively affected green behavior. The current study also confirmed that formalism negatively affected green behavior. Formalism is considered to be an important attribute of developing administration, and it is also considered to be a resistance to the adoption of administrative innovation. This study first confirmed the negative impact of formalism on the green behavior of civil servants.
\end{abstract}

Keywords: green behavior; green attitude; organization environmental strategy; green lifestyle; formalism

\section{Introduction}

The behavior of human beings has always been a major shaping factor for climate change and ecological catastrophes [1]. International organizations and government agencies must come up with clear environmental protection strategies to encourage and support their employees to act in a way that is environmentally friendly [2]. In global enterprises, environmental sustainability issues are always included in the organization's strategic planning [3]. To reduce negative impact on the environment and ecologies, organizational environmental strategy includes visions, goals, plans, and courses of action that are environmentally friendly [4]. Environmental strategy strengthens the voluntary green behavior of an organization's members through resource reuse, energy conservation, and waste reduction [5]. Conventionally, it has often been believed that employees' voluntary green behavior is key to an organization's ability to promote environmental protection [1]. It is very challenging for organizations to establish feasible environmentally friendly strategies $[6,7]$. The main reason is that the formulation of organizational strategies must consider factors such as stakeholder demands, required competencies, external forces, market conditions, organizational culture, and management structure. Therefore, it becomes difficult to formulate an organization's sustainability strategy [7]. How government agencies' environmental strategies affect civil servants' green behavior, where these strategies exert influence in society, has not been widely discussed.

In the 21st century, many corporate organizations have deemed employees' efforts in environmental protection and environmental compatibility to be an important task for their 
organizations [8]. Employees' green behavior in the office, such as paper recycling, doublesided printing, and water and electricity conservation, are all seen to be environmentally friendly $[9,10]$. Many organizations even incorporate green behavior into human resource management, including green recruitment and rewards. Recruitment of civil servants in Taiwan is conducted through examinations; green human resource management is not included within evaluations, and therefore most civil servants' green behavior in Taiwan is voluntary.

To urge governmental institutions and agencies to operate under the principle of environmental sustainability, the government of Taiwan has promoted the National Environmental Education Action Plan. In accordance with the Environmental Education Act, relevant measures include more than four hours of annual training in environmental education for civil servants, as well as the establishment of a certification system for environmental education institutions, their personnel, and institutional facilities [11]. Other measures include cultivating the environmental education industry and making environmental education universal.

On the basis of the "6 Rs" (Reduction, Reuse, Recycling, Energy Recovery, Land Reclamation, and Redesign) design concept, the idea of sustainable materials management, and the concept of material cycle society [12], Taiwan's governmental agencies promote the Resources Recycling and Reuse Plan to achieve the goals of maximizing resource use efficiency and minimizing environmental impact. However, can the above National Environmental Education Action Plan and Environmental Education Act really be effective? Or is it simply a formal response to organizational requirements, as described in administrative ecology [13]? The impact of formalism on the green behavior of civil servants is indeed worth exploring.

What is unique about the present study is the inclusion of formalism, which Riggs characterizes as characteristic of Asian administrative culture. Formalism refers to the gap between governmental laws and regulations and actual situations [13]. Although government agencies have enacted the National Environmental Education Action Plan and the Environmental Education Act, civil servants may not actually enforce these acts. However, according to the definition of formalism, there is a considerable gap between the actual implementation of civil servants and the legal norms. From another perspective, formalism believes that although the laws and regulations of developing countries are complete, the actual implementation level of civil servants is perfunctory. When the National Environmental Education Action Plan and the Environmental Education Act is not implemented by civil servants seriously, and there is no clear evaluation mechanism, the green behavior of civil servants becomes voluntary.

This research mainly aims to explore how the personal, working environment and family life factors of civil servants affect workplace green behavior. Personal factors include adoption of attitudes, intentions, and behaviors in the theory of planned behavior. Work environment factors include adoption of formalism and organizational environmental strategy. Family life is a factor that spans workplace and private life. This study specially introduces the formalism factor, which is an important influencing factor in public administration or green behavior research, but one that has hardly been explored. There is a gap between academic research and practice. This article hopes to obtain preliminary research contributions.

However, formalism has not been studied quantitatively. Science, technology, and the economy in Taiwan continue to develop apace, but government agencies and operation models still retain decades-old examination systems and permanent employment systems for civil servants. In this sense, government agencies still retain a portion of the formalism culture.

On the basis of Fox and Joiner's research, institutions with strong formalism will make civil servants feel that power is concentrated, and thus they are less willing to take responsibility [13]. Because of power concentration, civil servants have low self-efficacy 
and feel that they are unable to complete tasks [13]. In addition, civil servants with higher formalism are less interested in innovative topics and become used to routines [13].

Milne has pointed out that administrative systems with formalism lack pressure to achieve goals and does not have performance evaluations [14]. This is relatively unfavorable for the implementation of green behavior. At present, government agencies currently do not include green performance in performance appraisal management or performance reviews. Naturally, civil servants with high formalism are reluctant to practice green behavior. Another characteristic of organizations with high formalism is a lack of value systems that are commonly held between administrative supervisors and civil servants [14]. As a result, public administration does function effectively. Even if environmental protection policies and green procurement are announced, they may not be implemented. In conducting preliminary analysis, this article incorporates formalism, which is a rare approach in the administrative studies.

In recent years, environmental issues have received more and more attention, and a great deal of research has been conducted on the matter [15-17]. For business organizations, environmental protection and natural resources management have become the focus of their work $[18,19]$. As Dyllick and Hockerts argue, organizations must build sustainable communities to develop economic, social, and environmental assets [20]. Since government agencies are the planners of environmental protection policies, civil servants need to start with public service systems to establish a sustainable community.

Green behavior is also called environmentally sustainable behavior [21]. In the workplace, an individual's behavior that is conducive to environmental and sustainable development is called workplace green behavior $[8,22]$. Previous studies have specifically explored green behavior in the workplace $[10,23,24]$. Kirkwood and Walton point out that green behavior in the office includes recycling plans, promulgation of environmental protection policies, energy saving, water saving, and carbon reduction plans [25].

Norton et al. and Robertson and Barling divide environmental green behavior into two categories: that which is required by agencies, and that which is voluntary $[8,24,26]$. However, thus far, most green behavior in the workplace is not seen to be required by agencies, but rather voluntary behavior, which is at odds with agencies' expectations. Institutions and agencies may formulate environmental protection policies and green procurement plans to encourage green behavior. Voluntary green behavior resembles organizational citizenship behavior, in that it is supported by the organizational environment, but is not necessarily required [8].

Previous research on green behavior has mostly focused on consumption. Only in the past 10 years has research gradually begun to explore green behavior in the workplace [8,27]; rarely has the literature focused on the green behavior of government agencies. Triandis defined behavioral intentions as a guide for an individual to act in a certain direction [28]. Therefore, the intention of green behavior is considered to be an indication of employees' environmentally friendly behavior in the workplace [29]. Civil servants' perceptions and intentions regarding green behavior will affect their green behavior practices.

Previous studies have found that employees spend at least $8 \mathrm{~h}$ a day in their organizations, and that green behavior by them can reduce damage to the environment by a large amount $[1,30]$. Most employee participation in green behavior is viewed as voluntary, but some studies consider it to be required [31]. Green behavior is a preventive behavior (involving, among other things, resource recycling, double-sided printing, water saving, and electricity conservation) prior to environmental damage occurring. Therefore, for civil servants to conduct green behavior, it is necessary for them to believe that their daily green behavior can protect the environment [32]. Although green behavior is categorized as voluntary behavior, it is generally believed that agencies need to support civil servants and convince them that green behavior is worth doing [33,34].

An individual's more positive behavior towards the environment can be called proenvironmental behavior or green behavior. Such behavior is also the type that is friendly to the environment, or which makes the environment sustainable $[8,35]$. Some scholars argue 
that pro-environmental behavior is similar to green behavior [21], and that such behavior either in the market or in the workplace will allow the environment to develop sustainably.

Attitude itself has been extensively studied by social psychologists, and the findings have been applied in different academic fields. Environmental attitude is defined as an individual's belief in friendly environmental activities [36,37]. Many prior studies have confirmed that green attitude affects green behavior and that there is a linear relationship between the two [10,37].

From the perspective of waste prevention management, the gap between green attitude and green behavior exists [38]. Many people think that waste disposal is wrong, but they did not implement it by themselves. The reasons include lack of participation, lack of knowledge of waste management, and insufficient education. This study aimed to explore whether the green attitude of civil servants is positively linked to green behavior, or whether there is a gap between green attitude and green behavior, resulting in no significant positive relationship between green attitude and green behavior. The obstacles that affect the effective implementation of the waste prevention program also include political, cultural, and environmental factors [38]. This study also introduces formalism factors to explore how administrative formalism affects green behavior in public sector. The lack of enforcement of policies and laws is also one of the reasons why waste prevention management cannot succeed $[38,39]$. Therefore, this study also introduces organizational environmental strategy and explores the relationship between environmental strategy and green behavior. Social-cultural barriers include lack of engagement, lack of co-operation, and negative attitudes [39]. This research introduces the green family life factor to understand whether family green activity participation can change the green behavior of civil servants in the workplace.

The environment-centric philosophy argues that those who are more willing to protect the earth and natural resources are more likely to practice green behavior [40]. Haynes and Fryer also show that employees with good attitudes will increase the probability of their intention and behavior to provide good services [41]. The relationship between attitude and behavioral intention can be applied to the relationship between green attitude and green intention $[42,43]$.

The above-mentioned personal factors of civil servants include green attitudes, intentions, and behaviors, which are adopted from the TPB theory. Environmental factors include organizational environmental strategy and formalism of administrative ecology. In accordance with social learning theory, enrichment model, spillover model, and border theory, green lifestyles are also considered to be related to green behavior in the workplace. Therefore, this study also adds factors such as green lifestyle, formalism, and organization environmental strategy to discuss their impact on civil servants' green behavior.

This study summarizes the past literature reviews in Table 1 . Most previous studies discussed TPB (Theory of Planned Behavior) theory alone, or discussed the single relationship between organizational environmental strategy, green family life, and green behavior. The organizational level, personal work, and personal life levels are rarely integrated and studied together. In particular, there has not been any research in the past that incorporated the characteristics of formalism in developing countries into the study of green behavior.

Table 1. Literature table.

\begin{tabular}{llll}
\hline Author & Title & Methodology & Finding \\
\hline & $\begin{array}{l}\text { Who contributed to "corporation } \\
\text { green" in China? A view of public- } \\
\text { and private-sphere } \\
\text { pro-environmental behavior among } \\
\text { employees. }\end{array}$ & One-way ANOVA & $\begin{array}{l}\text { Respondents who are unmarried, } \\
\text { younger, and less educated have } \\
\text { lower PEB scores. }\end{array}$ \\
& $\begin{array}{l}\text { Corporate Environmental Strategy } \\
\text { and Voluntary Environmental } \\
\text { Behavior-Mediating Effect of } \\
\text { Psychological Green Climate }\end{array}$ & $\begin{array}{l}\text { Structural equation modeling } \\
\text { (SEM) }\end{array}$ & $\begin{array}{l}\text { The corporate environmental } \\
\text { strategy influences voluntary } \\
\text { environmental behavior through } \\
\text { psychological green climate. }\end{array}$ \\
\hline
\end{tabular}


Table 1. Cont.

\begin{tabular}{|c|c|c|c|}
\hline Author & Title & Methodology & Finding \\
\hline Zhao et al. [4] & $\begin{array}{l}\text { How Proactive Environmental } \\
\text { Strategy Facilitates Environmental } \\
\text { Reputation: Roles of Green Human } \\
\text { Resource Management and } \\
\text { Discretionary Slack }\end{array}$ & $\begin{array}{l}\text { Structural equation modeling } \\
\text { (SEM) }\end{array}$ & $\begin{array}{l}\text { Green human resource } \\
\text { management plays an important } \\
\text { role in implementing firms' } \\
\text { environmental strategies and } \\
\text { promoting firms' environmental } \\
\text { reputation. }\end{array}$ \\
\hline Wijethilake [5] & $\begin{array}{l}\text { Proactive sustainability strategy and } \\
\text { corporate sustainability performance: } \\
\text { The mediating effect of sustainability } \\
\text { control systems }\end{array}$ & $\begin{array}{l}\text { Partial least squares structural } \\
\text { equation modeling (PLS-SEM) }\end{array}$ & $\begin{array}{l}\text { The sustainability control systems } \\
\text { partially mediate the relationship } \\
\text { between proactive sustainability } \\
\text { strategy and corporate } \\
\text { sustainability performance. }\end{array}$ \\
\hline Han et al. [6] & $\begin{array}{l}\text { How Responsible Leadership } \\
\text { Motivates Employees to Engage in } \\
\text { Organizational Citizenship Behavior } \\
\text { for the Environment: A } \\
\text { Double-Mediation Model }\end{array}$ & $\begin{array}{l}\text { Structural equation model } \\
\text { (SEM) }\end{array}$ & $\begin{array}{l}\text { Responsible leadership positively } \\
\text { influences environmental } \\
\text { organizational citizenship } \\
\text { behavior, as well as autonomous } \\
\text { and external environmental } \\
\text { motivation. }\end{array}$ \\
\hline Kitsios et al. [7] & $\begin{array}{l}\text { Corporate Sustainability Strategies } \\
\text { and Decision Support Methods: A } \\
\text { Bibliometric Analysis } \\
\text { Employee Green Behavior: A }\end{array}$ & $\begin{array}{l}\text { Webster's and Watson's (2002) } \\
\text { methodology }\end{array}$ & $\begin{array}{l}\text { Managers need to effectively } \\
\text { integrate corporate sustainability } \\
\text { strategies and business strategies. } \\
\text { It is confirmed that there is a }\end{array}$ \\
\hline Norton et al. [8] & $\begin{array}{l}\text { Theoretical Framework, Multilevel } \\
\text { Review, and Future Research Agenda }\end{array}$ & & $\begin{array}{l}\text { difference between required EGB } \\
\text { and voluntary EGB. }\end{array}$ \\
\hline $\begin{array}{l}\text { Bissing-Olson } \\
\text { et al. [10] }\end{array}$ & $\begin{array}{l}\text { Relationships between daily affect } \\
\text { and pro-environmental behavior at } \\
\text { work: The moderating role of } \\
\text { pro-environmental attitude }\end{array}$ & HLM & $\begin{array}{l}\text { Studies have confirmed that } \\
\text { pro-environmental attitude } \\
\text { positively affects } \\
\text { pro-environmental behavior. }\end{array}$ \\
\hline Milne [14] & $\begin{array}{l}\text { Mechanistic and Organic Models of } \\
\text { Public Administration in Developing } \\
\text { Countries }\end{array}$ & & $\begin{array}{l}\text { The loyalty of civil servants in } \\
\text { developing countries to formal } \\
\text { and informal organizations is not } \\
\text { the same. The loyalty gap also } \\
\text { causes the administrative agency } \\
\text { to be inefficient. }\end{array}$ \\
\hline Greaves et al. [29] & $\begin{array}{l}\text { Using the theory of planned behavior } \\
\text { to explore environmental behavioral } \\
\text { intentions in the workplace }\end{array}$ & $\begin{array}{l}\text { Confirmatory factor analysis } \\
\text { (CFA) }\end{array}$ & $\begin{array}{l}\text { In addition to employee } \\
\text { intentions positively affect } \\
\text { environmental behaviors. } \\
\text { Employee intentions also mediate } \\
\text { the relationship between } \\
\text { antecedent beliefs and } \\
\text { environmental behaviors. }\end{array}$ \\
\hline
\end{tabular}

\section{Theoretical Basis}

Formalism in this study, as proposed by Riggs, has rarely been applied to empirical studies of administrative management. F. W. Riggs proposed the concept of formalism that occurs in administrative agencies and developed Fused-Prismatic-Diffracted models from the perspectives of ecology and comparative administration to understand administrative structures and organizational behavior in the developing countries [44,45]. The administrative characteristic in many developing countries differs from the decentralization of power in developed countries. Therefore, Riggs proposed the Ecology of Administration. He analyzes the relationship between administrative system and ecological factors, including social structure, traditions, economic situation, and political symbols [44,45].

The Prismatic Model proposed by Riggs has three important features: heterogeneity, formalism, and functional overlapping [44,45]. Heterogeneity refers to the coexistence of tradition and modernity. Formalism refers to the gap between governmental laws and regulations and actual situations. In other words, announced policy goals and actual performance are not consistent, and policy performance is lower than expected policy goals. 
Functional overlapping refers to the same function appearing in different government departments. Heterogeneity and functional overlapping primarily describe administrative environment and structure. This article adopts formalism to measure whether green policies and programs are faithfully implemented and whether they have a negative effect on green behavior.

This study relies on the Theory of Planned Behavior to explain relationships between green attitude, green behavioral intentions, and green behavior. The Theory of Planned Behavior is derived from the theory of reasoned action, which was first developed by Ajzen [46]. The theoretical model of planned behavior predicts behavioral intentions and eventually actual behavior through attitudes, subjective norms, and perceived behavioral control [47]. Subjective norms refer to important people and groups in the organization that will support and recognize certain behavior. Individuals will feel the perceived social pressure, and therefore they must obey the expectations of these people and perform these expected behaviors [47]. In other words, subjective norms are more applicable to compulsive green behaviors, rather than voluntary green behaviors defined in this study. In addition, Taiwan's government agencies have not incorporated green performance into human resource management, nor have they implemented green employment; this study does not include subjective normative factors.

Perceived behavioral control refers to how easy and difficult it is for an individual to perform a certain behavior. Perceived behavioral control will vary as the environment changes. The study of Bouarar and Mouloudj pointed out that perceived behavioral control is not an important factor in predicting behavioral intention [48]. Ajzen himself has pointed out that in the absence of problem of volitional control over the performance of the behavior, TPB theory cannot predict behavioral intentions and actual behaviors [49]. Volition is a mental state oriented towards achieving goals. When individuals can control their volition and reduce environmental barriers, they can successfully achieve their goals. However, this research has always defined the green behavior of civil servants as voluntary behaviors, not compulsive behaviors. Civil servants do not implement green behavior in order to achieve their job goals. Therefore, this study excludes the use of perceived behavioral control factor.

In addition, this study is also not intended to verify or supplement the theory of planned behavior, and thus it only includes three factors: attitude, behavioral intention, and behavior. When the green attitude is higher, the probability of green behavioral intention and actual green behavior is higher.

Attitude is considered to be a person's positive or negative evaluation of a particular behavior [49]. Behavioral belief refers to the belief that an individual chooses to behave in a certain way. Evaluation means evaluating a given positive or negative deed after acting in a certain way [49]. Behavioral intention shows a certain behavioral direction. It is also an antecedent of actual behavior [47]. When green behavioral attitude is high, green behavioral intention will also be high.

This study relies on social learning theory, enrichment model, spillover model, and border theory to explore the relations between green life and green behavior in the workplace. Social learning theory argues that the behavior of an organization's employees is based on learning from other organizations [50]. These learned values and deeds come from the learning of other goals and behavior [51]. According to Bandura, social learning is to observe social phenomena and norms, and imitate them [52]. Social learning theory points out that individuals observe, learn, and imitate the behaviors of others. Environment and cognitive factors will affect the individual's learning process and behavior. As organizational environmental strategy makes clear environmental protection policies, standards, and measures, members of organizations will see organizational environmental strategy as a model and practice green behavior.

The enrichment model argues for the concept of accumulating and sharing resources in different domains [53]. In other words, the environmental protection in the family life will have a positive impact on diversified life, including the workplace [54]. Environmental 
protection resources and experience in the family will improve role-playing performance in another domain [55].

The spillover model indicates that experiences are transferable in different domains of life and work, including positive and negative spillover effects [56]. For example, satisfaction in life can spill over into job satisfaction perception. Some scholars also point out that emotions, attitudes, and deeds may spill over from life to work [56,57]. Regarding the difference between the enrichment model and the spillover model, the enrichment model emphasizes resource sharing and positive effects. The spillover model argues that both positive and negative effects may spill over, and it does not mention resource sharing.

From the perspective of border theory, individuals are border-crossers between life and workplace [58]. They will make resource conversions and decisions between life and workplace. For example, employees will discuss family needs with their supervisors to improve the problems they encounter in the workplace. Green family lifestyles can also spill over into workplace.

\section{Literature Review and Hypotheses Development}

Attitude can be observed in a person's beliefs, feelings, and deeds [59]. Green attitude is often used interchangeably with several terms, including ecological attitude, environmentally friendly attitude, and environmental sustainability attitude. McIntyre and Milfont show that environmental attitude is the assessment of natural environment quality [60]. Members' attitudes toward and perceptions of organizational environmental sustainability policies and courses of action will affect their environmental sustainability intentions and behavior [8].

It is believed that personal attitude and perception will influence his or her intention and behavior $[61,62]$. Attitude is defined as the degree to which a person likes or dislikes a certain behavior [49]. Therefore, green attitude can be defined as positive or negative evaluation of green behavior or green-related issues. In many social psychology theories, attitude is a key factor in a person's behavior and decision-making process [63].

An individual's green attitude obviously is an antecedent of green behavioral intention $[62,64]$. Many previous studies have confirmed that when attitude towards environmentally friendly products is better, the probability of purchasing environmentally friendly products is higher $[61,62,65]$. For civil servants, when their green attitude is high, their green behavioral intention will inevitably increase.

According to the Theory of Planned Behavior developed by Ajzen [46], individual behavior can be predicted by attitude, subjective norms, and perceived behavioral control. Attitudes, subjective norms, and perceived behavioral control first form behavioral intention which then influences one's behavior [47].

\section{Hypothesis 1 (H1). Green attitude positively affects green behavioral intention.}

The personal factors in this article adopt the attitude, intention, and behavior of TPB theory. So-called green behavior is defined as an individual's daily behavior to reduce damage to the natural environment [66]. For Ones and Dilchert, green behavior for the environment is the behavior of employees in the office who devote themselves to environmental sustainability [35].

In recent years, Norton and other scholars have divided green behavior into required and voluntary categories $[8,26]$. With required green behavior, some business organizations incorporate green human resource management and rewarded and supported green behavior. Required green behavior is a response to the interests, programs, and policies that prioritize environmental protection. Voluntary green behavior is similar to organizational citizenship behavior, which is supported by organizations and society [8].

Twenty years ago, studies showed that green behavioral intention is the antecedent of green behavior. Therefore, many organizational researchers have regarded behavioral intention as a proxy variable for behavior itself [29]. A study by Bosco et al. shows that perhaps the relationship between behavioral intention and actual behavior is not very 
strong, but the relationship does exist [67]. Bamberg and Möser, however, find that the correlation between green behavioral intention and actual green behavior is relatively strong, as high as 0.5 [68]. Additionally, in an office study, Holland et al. found that there is a strong relationship between environmental protection intentions and resource recycling behavior [69].

According to the theory of planned behavior, behavioral cognition and intention will affect actual behavior [49]. From the perspective of goal setting theory, when employees are motivated for work goals, they will be able to complete the work more efficiently [70]. When civil servants themselves are willing to take environmental protection as their goal, the probability of their green behavior is high.

Some social psychologists have pointed out that intention is considered to be the best predictor for actual behavior [64]. The measurement of behavioral intention is the appearance of the thought of behaving in a certain way. In the theory of planned behavior, attitudes, subjective norms, and perceived behavioral control affect behavioral intention, which in turn affects actual behavior [71,72]. It is also used to explain environmental behavior [68]. According to the theory of planned behavior, behavioral intentions are also affected by attitudes $[49,73]$.

Steg and Vlek argue that green behavior reduces damage to the environment, and at the same time, it is also a behavior that is beneficial to the environment [66]. Green behavior in marketing includes purchasing and using environmentally friendly products, conducting waste management, and recycling [74]. Psychological intentions are considered to be antecedents of actual behavior [47]. When an individual has an attitude of affection, their behavioral intentions will be raised. According to the theory of planned behavior, green behavior intentions will affect green behavior. When civil servants' green behavior intentions are high, the probability of their green behavior will also be high.

As mentioned above, green attitude will affect green behavior intention and behavior [61,62], and behavior intention has always been a proxy variable of actual behavior. Taking the purchase of green products as an example, related studies have also confirmed that consumers with green attitudes are more likely to purchase green products intent and behavior $[62,65]$. The theory of planned behavior and some socio-psychological studies have also confirmed that behavioral intentions will affect actual behavior [49,71]. Therefore, this study also believes that green intention will mediates the relationship between green attitude and green behavior.

Hypothesis 2a (H2a). Green behavior intention positively affects green behavior.

Hypothesis $\mathbf{2} \mathbf{b} \mathbf{( H 2 b )}$. Green behavior intention mediates the relationship between green attitude and green behavior.

Many previous studies have confirmed that environmental contexts affect green behavior [75]. Organizational culture and organization climate will affect employees' attitudes and perceptions [76]. According to Riggs, administrative organizations in Asian countries are generally characterized by formalism. An important feature of formalism in public affairs is that self-interest weighs more than public interest [13]. Civil servants try their best to avoid trouble. Fox and Joiner point out that formalism is characterized by red tape that impedes policy implementation [13]. In addition, they find that civil servants with strong formalism care more about self-interest, rather than the of public interest [13]. Although government agencies may announce environmental protection policies, for permanently employed civil servants, implementing these policies makes no major difference. This is especially true when it comes to innovative policies. Those who are not personally benefited are less willing to implement them.

Fox and Joiner mention that countries with thriving formalism are also characterized by harsh authoritarianism; they pay less attention to people's needs [13]. Because of authoritarian rule in these countries, their administrative communication systems are poor, and their command systems are not very smooth. These factors result in administrative in- 
efficiency [13]. Third, formalism often goes hand in hand with paternalist leadership. This leads to less willingness among civil servants to practice green behavior [13]. Green behavior has not been included in human resource management in Taiwan, being still considered a voluntary behavior. Even though the central and local governments have announced environmental protection policies and measures, due to poor communication, inefficiency, and low self-efficacy, civil servants may still be unwilling to conduct green behavior.

Milne also finds that an administrative system with high formalism is characterized by static control and is not receptive to change and related innovation [14]. Public agencies primarily do paperwork; they do not faithfully implement policies, they pay more attention to ritualistic procedures, and they are more resistant to innovation [14]. Green behavior has become a global green management trend in the past 10 to 20 years. Therefore, traditional public service agencies are relatively indifferent to it and will not take it seriously.

In addition, Milne finds that the relationships between administrative supervisors and subordinates are built on legitimate foundation, but their coordination is poor [14]. Furthermore, individuals' goals are inconsistent with organizations' goals [14]. Even though an agency announced a green behavior policy, not all civil servants will implement it seriously and treat it as a personal work objective. Relevant studies in other developing countries show that trust between civil servants and colleagues is not high [77].

There are not many empirical studies on formalism in the public administration field. Does the formalism of civil servants affect green behavior through green behavior intention? Or does formalism directly affect green behavior? Thus far, there is no theoretical and empirical evidence to prove it. The current generalization of formalism from the literature review, including obstruction of policy implementation, lack of administrative efficiency, rejection of innovation, resistance to change, and low self-efficacy, all tend to be behaviororiented. The path through which individual behavior affects behavioral intentions has conflicted with the TPB theory's intentions affecting actions [46,47]. Therefore, this study establishes the hypothesis that formalism negatively affects green behavior.

\section{Hypothesis 3 (H3). Formalism negatively affects green behavior.}

Government agencies also need to plan environmental protection strategies. When civil servants' green cognition and knowledge are linked to agencies' environmental protection strategies, it is easier to produce green environmental protection behavior. In line with Article 96 of Taiwan's Government Procurement Act [78], agencies may stipulate in tender documents that preference shall be given to a product that has been permitted to use a label of environmental protection approved by the government. Preference shall also be given where a product or its raw material is manufactured, used, and disposed of in such manner that conform to recycled materials, returnable products, low pollution, or energy-saving requirements. When agencies are willing to consider environmental protection issues, issue environmental protection publications, and prioritize the purchase of environmental protection products, civil servants' green behavior will be strengthened. Some scholars have pointed out that an announcement of organizational environmental strategy will be interpreted by employees as organization's support for and investment in green behavior, which in turn leads to green behavior [79]. Recently, some scholars' findings also show that employees' knowledge and understanding of organizational environmental strategy can indeed enhance their green behavior $[8,80]$.

Previous studies have indicated that predictors of environmental protection behavior have not been fully explored. Organizational environmental strategy is one of them $[3,6]$. The knowledge of an organization's employees about the environment and employees' approval of their organization's investments in environmental protection will affect the sustainable development of environmental ecology. When employees are unwilling to invest in the organization's environmental protection strategy, it will cause a failure in an environmentally friendly program [3]. The success and failure of an organizational environmental strategy depends on whether the members of a given organization are willing to implement it voluntarily [81]. From the perspective of social identity theory, 
organizational environmental strategy and employees are part of a given organizational environment. Green behavior occurs only when employees show approval of organizational environmental strategy [3].

Some studies find that organizational environmental strategy can increase willingness to become psychologically green, and thereby increase the probability of green behavior [82]. When an organization's members have positive evaluations of organizational environmental strategy and agree with environmental protection strategy, policy, and plan, it is easier to produce green behavior $[82,83]$. This also means that the perception of organizational environmental strategy will positively affect green behavior.

This study attempts to explore the relationship between organizational environmental strategy and green behavior intention. There is no literature on the relationship between organizational environmental strategy and green behavior intention has been found, and most of the literature discusses the relationship between organizational environmental strategy and green behavior $[79,83]$.

Hypothesis 4 (H4). Organizational environmental strategy perception positively affects green behavior.

In order to strengthen an organization's green behavior, it is necessary to understand environmental protection behavior outside the workplace, such as an individual's green life. Each individual's daily lifestyle affects the natural environment [84]. Past studies on work-life have shown that workplace and private life are interrelated [56].

Personal, interpersonal, situational, cultural, and structural factors will affect the environmental protection behavior of an organization's members. Employees also learn environmental behavior from their private life. Environmental protection behavior in an individual's private life will also extend to consumer behavior, including selection, purchase, and use of environmentally friendly products [85]. These daily environmentally friendly deeds can easily be transferred to the workplace. The current literature has confirmed that private life and workplace influence each other [86]. As the logic goes, it can be inferred that environmental protection behavior in private life and in the workplace will influence each other and be a learning model for each other. From the perspective of social learning theory, the main object of learning and imitation is behavior [51,52]. Therefore, this study directly connects green lifestyle to green behavior, and does not consider the relationship between green lifestyle and green behavior intention. From the perspective of the Cognition-Affect-Conation Model, behavior includes three time evolution stages: cognitive (thinking), affective (feeling), and conative (doing) [87]. Green lifestyle and green behavior in this study are both measures of conative stage's behavior. It is more reasonable for green lifestyle to directly connect to green behavior, rather than to green behavior intention.

Work life and private life can be regarded as separate and independent domains [86]. Although they are independent from each other, they can influence each other [56]. On the basis of different theories, this study argues that civil servants' green life will affect their green behavior in the workplace. From the perspective of enrichment model and spillover mode, an individual's experience of green family life can reinforce green behavior in the workplace. In other words, green behavior spills over from family life into workplace. In a study by Rashid et al., environmentally friendly deeds in personal life and in the workplace influence each other. The environmental protection resources and experience in the family life are transferred to agencies and organizations [88]. Border theory also argues that different domains of life will affect each other, including personal life and workplace.

Green homes and green work are increasingly valued. Environmental value and behavior in family life and in the workplace are compatible. Some scholars who study green behavior at home and in the workplace find that behavior in these two domains will reinforce each other [89]. In other words, environmentally friendly behavior in green family life may be extended to workplace.

People's lifestyles are different. Some pay more attention to environmental protection, whereas others do not. This creates different degrees of impact on the environment [84]. 
Previous research also shows that daily life and work situations will affect each other [56,90]. From the perspective of human resources, Muster and Schrader find that family's green behavior will also influence the green behavior in the workplace through the encouragement of human resource management [89].

According to border theory, the content that affects each other in family and work includes value, skills, and behavior [58]. Border theory believes that when the behaviors of the workplace and the family are very similar, the behaviors in one area will spill over to the other. Border theory links behaviors in different fields (family, workplace) and does not link the relationship between value, skill, and behavior. Therefore, this study directly connects green family life behavior to green behavior in workplace and does not connect the relationship between green family life and green behavior intention.

An individual's green family life is their environmental behavior at home, including water saving, electricity saving, energy saving, and recycling [91-94]. Those who already behave environmentally friendly at home are more likely to buy environmentally friendly products [91,95]. According to some studies, green actors in the workplace will pay more attention to environmental damage and adopt environmentally friendly consumption behavior [96]. Green life habits can easily produce environmentally friendly activities and behavior in other domains of life [91,92,95].

Hypothesis 5 (H5). Green family life positively affects green behavior.

All hypothetical relationship diagrams are shown in Figure 1.

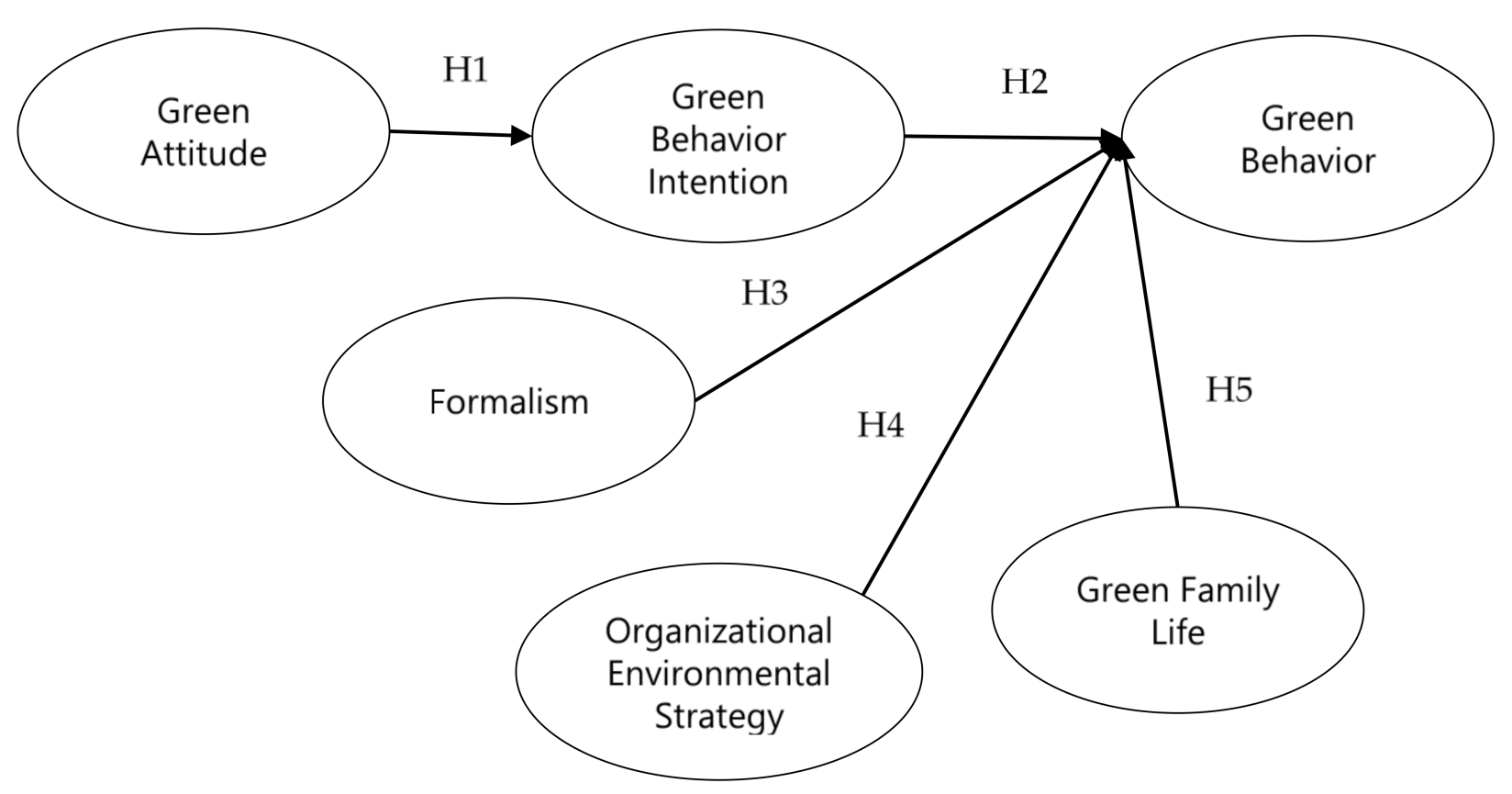

Figure 1. Conceptual framework.

\section{Materials and Methods}

\subsection{Sample, Tools, and Procedure}

In this study, civil servants in Taiwan were surveyed. A total of 430 questionnaires were distributed via convenience sampling and 315 samples were collected. The sample recovery rate was $73.26 \%$. Seven samples with too many missing values were deleted, and finally 308 valid samples were adopted. Regarding the basic information of the interviewees, in terms of gender, males accounted for $44.6 \%$, and females accounted for $55.4 \%$. In terms of age, $20.8 \%$ of the sample were people between 20 and 29 years old, $35.1 \%$ 
were people between 30 and 39 years old, $26.0 \%$ were people between 40 and 49 years old, $14.9 \%$ were people between 50 and 59 years old, and $3.2 \%$ were people 60 years old or older. In terms of education level, junior college degrees accounted for $22.6 \%$, college degrees accounted for $67.9 \%$, and postgraduate degrees accounted for $9.5 \%$. In terms of length of employment, 3 years or less accounted for $23.9 \%, 4$ to 6 years accounted for $26.2 \%$, and 7 years or more accounts for $49.8 \%$. In terms of marriage, unmarried individuals accounted for $43.3 \%$, and married individuals accounted for $56.7 \%$. We found the population distribution of public servants in 2020 from the Ministry of Civil Service of Taiwan. After statistically weighting the sample, we performed a chi-squared test on the population and the sample. The significance of the chi-squared tests for sex, age, and education level were 1, 0.837, and 0.578, respectively, all of which were greater than 0.05 . This confirmed that the research sample is representative.

This study conducted a normality analysis for all items; the skewness statistics ranged from -1.20 to 0.10 , and the kurtosis statistics ranged from -1.09 to 1.96 . The sample in this study conformed to the normal distribution.

This research used $G^{*}$ Power software (Düsseldorf, Germany; version 3.1.9.7) to calculate the sample size. When the effect size was set to $0.15, \alpha$ err prob $=0.05$, and Power $(1-\beta$ err prob) $=0.95$. The sample required for calculation was 129 , and the sample (308) in this study was exceeded.

In this study, the 50 samples collected at the earliest and 50 samples at the latest were selected for non-response analysis. After paired $t$-test was used, we found that the $t$-value of all factors was between -0.8 and 1.17; the significance was between 0.25 and 0.78 . The above values indicate that the non-response bias in this study did not occur. All sample basic information is presented in Table 2 .

Table 2. Sample basic information.

\begin{tabular}{llcc}
\hline Gender & Percentage (\%) & Seniority & Percentage (\%) \\
\hline Male & $44.6 \%$ & 3 years or less & $23.9 \%$ \\
Female & $55.4 \%$ & 4 to 6 years & $26.2 \%$ \\
\hline Age & & 7 years or more & $49.8 \%$ \\
\cline { 3 - 4 } $20-29$ years old & $20.8 \%$ & Marriage & $43.3 \%$ \\
$30-39$ years old & $35.1 \%$ & Unmarried & $56.7 \%$ \\
$40-49$ years old & $26.0 \%$ & Married & \\
$50-59$ years old & $14.9 \%$ & & \\
60 years old or older & $3.2 \%$ & & \\
\hline Education level & & & \\
Junior college & $22.6 \%$ & & \\
College & $67.9 \%$ & & \\
Postgraduate & $9.5 \%$ & & \\
\hline
\end{tabular}

\subsection{Measures}

\subsubsection{Dependent Variables}

Green behavior was all modified from the scale of Ajzen's theory of planned behavior [49]. Subjects rated their responses on a seven-point scale, ranging from 1 (strongly disagree) to 7 (strongly agree). The internal reliability Cronbach's $\alpha$ of the scale was 0.88 .

\subsubsection{Mediating Variables}

Green behavioral intention was modified from the scale of Ajzen's theory of planned behavior [49]. Subjects rated their responses on a seven-point scale, ranging from 1 (strongly disagree) to 7 (strongly agree). The internal reliability Cronbach's $\alpha$ of the scale was 0.93 . 


\subsubsection{Independent Variables}

Green attitude was modified from the scale of Ajzen's theory of planned behavior [49]. Organizational environmental strategy was modified from the scale developed by Ramus and Steger [79]. Green lifestyle was modified on the basis of the questionnaire from Ragas et al. [97]. In line with the definition of formalism (that is, expectations and outcomes do not match), this research also quoted the scale developed by Liu [98]. First, I think that operating procedures established by government agencies may not necessarily be implemented. Second, in my opinion, many procedures in civil service agencies are only used as references for implementation. Third, I believe that there is a gap between many of government agencies' policies and their actual implementation. Only the green attitude uses a five-point scale; subjects responded to the other variables using a seven-point scale, ranging from 1 (strongly disagree) to 7 (strongly agree). For items whose content validity was obviously poor, even though they had passed reliability and validity tests, this study deleted them. The Cronbach $\alpha$ values of all research dimensions were between 0.77 and 0.96 , which was higher than the minimum standard of 0.60 set by Nunnally [99].

\subsubsection{Controlling for Common Method Variance (CMV)}

Common method variance is a type of variance caused by the measurement method. It leads to internal consistency errors, and thus needs to be controlled for [100-102].

In terms of pre-survey avoidance and post-survey verification of common method variance, this study's questionnaire used the self-reported method, and thus common method variance problems were possible. In order to ensure that research results will not be greatly affected by common method variance, this study conducted the survey anonymously and adopted the Likert 5-7 scale to reduce the possibility of common method variance issues [100]. In addition, the questionnaire design in this research met specific standards and operating procedures. The question design took into account the principles of simplicity, clarity, and understandability. Any questions that could confuse interviewees, be interpreted differently, or would be difficult to answer were avoided as much as possible.

In terms of post-survey verification, this study relied on Harman's one factor test. The factor explanation of the unrotated first principal component in exploratory factor analysis was only $45.36 \%$. This is not excessively high and demonstrates that common method variance was not a serious issue for this research.

In this study, a retention factor that is not related to the research model was selected as the marker variable [103]. The relationship between the marker variable established in this study and all variables is not significant. The coefficient and significance of the research model had hardly changed, except that formalism has dropped from -0.13 to -0.06 . The analysis of marker variable proved once again that the conceptual model of this study does not have the problem of CMV.

\subsubsection{Validity and Reliability Analysis}

This study used Smart PLS Software (AL, United States; version: 2.0) to test the reliability and validity of items by confirmatory factor analysis (CFA). The model fit index was observed to verify the appropriateness of the model and construct validity. This is also one of the reasons that confirmatory factor analysis is considered to be more accurate and credible.

In terms of factor loading $\lambda$ value, factor loading $\lambda$ values for all items in the research dimensions ranged from 0.62 to 0.99 . They were greater than 0.5 , which conforms to the suggested value of Hair et al. $(>0.5)[104,105]$. This means that the items in this study's scales achieved an acceptable level of reliability. The confirmatory factor analysis is a type of factor analysis. The first step of this analysis was to verify the loading factor of items. All the items loading $t$-values in this study achieved a statistically significant level, and this also confirmed the construct validity and convergent validity of the research dimensions.

The composite reliability (CR) of latent variables can measure the consistency of research dimensions' internal variables. When the $C R$ value of a latent variable is high, it 
means that observational variable is highly correlated. According to Hair et al., the CR value must be greater than 0.7 [104]. The CR values of latent variables in this study were between 0.81 and 0.97 , greater than 0.7 , indicating that latent variables in this study had good internal consistency.

Average variation extraction (AVE) refers to the percentage of latent variable that can be tested through observational variable. It can be used to judge reliability, discriminant validity, and convergent validity. According to Fornell and Larcker's recommendations, when AVE value was greater than 0.5, it indicated that research dimension had convergent validity [106]. The AVE values of latent variables in this study, ranging from 0.58 to 0.83 , were all greater than 0.5 (Table 3 ), indicating that the latent variables in this study had good discriminant validity and convergent validity.

Table 3. Item loading and model fits.

\begin{tabular}{|c|c|c|c|c|c|}
\hline Variables & Items & $\begin{array}{l}\text { Lambda } \\
\text { Loading }\end{array}$ & $t$-Value & AVE & $\begin{array}{l}\text { Cronbach's } \\
\text { Alpha }\end{array}$ \\
\hline \multirow{6}{*}{ Green behavior [49] } & $\begin{array}{l}\text { I reduce waste by reusing water bottles, paper, plastic, and } \\
\text { other items. }\end{array}$ & 0.82 & 27.97 & \multirow{6}{*}{0.91} & \multirow{6}{*}{0.88} \\
\hline & $\begin{array}{l}\text { When not using the shredder, I turn off the device to reduce energy } \\
\text { consumption. }\end{array}$ & 0.79 & 24.67 & & \\
\hline & $\begin{array}{l}\text { I choose a more environmentally friendly way of commuting } \\
\text { to work }\end{array}$ & 0.72 & 20.34 & & \\
\hline & I try to take the stairs as much as possible and use less elevators. & 0.78 & 23.58 & & \\
\hline & I use email instead of paper letters. & 0.79 & 22.24 & & \\
\hline & I use the carbon-saving, double-sided printing method for printing. & 0.84 & 34.04 & & \\
\hline \multirow{6}{*}{$\begin{array}{l}\text { Organization } \\
\text { environmental } \\
\text { strategy [79] }\end{array}$} & $\begin{array}{l}\text { The government department where I work will release } \\
\text { environmentally related policies. }\end{array}$ & 0.91 & 66.11 & \multirow{6}{*}{0.97} & \multirow{6}{*}{0.96} \\
\hline & $\begin{array}{l}\text { Government departments will release annual } \\
\text { environmental reports. }\end{array}$ & 0.93 & 92.62 & & \\
\hline & $\begin{array}{l}\text { Government departments will use environmental } \\
\text { management systems. }\end{array}$ & 0.93 & 82.22 & & \\
\hline & Working institutions will implement green education and training. & 0.91 & 47.93 & & \\
\hline & $\begin{array}{l}\text { The working agency has established an environmental } \\
\text { protection unit. }\end{array}$ & 0.91 & 57.10 & & \\
\hline & $\begin{array}{l}\text { The working agency will cooperate with suppliers with green } \\
\text { environmental protection certification }\end{array}$ & 0.86 & 33.73 & & \\
\hline \multirow{5}{*}{ Green attitude [49] } & I think saving energy is necessary. & 0.85 & 22.28 & \multirow{5}{*}{0.94} & \multirow{5}{*}{0.92} \\
\hline & I think it is wise to save energy. & 0.87 & 21.76 & & \\
\hline & I believe saving energy is useful. & 0.90 & 45.32 & & \\
\hline & I understand the environmental issues related to global warming. & 0.86 & 20.16 & & \\
\hline & I understand the air pollution caused by dioxin. & 0.90 & 36.82 & & \\
\hline \multirow{5}{*}{ Green lifestyle [97] } & $\begin{array}{l}\text { I participate in tree-planting projects and other eco-friendly } \\
\text { activities in the community. }\end{array}$ & 0.88 & 53.10 & \multirow{5}{*}{0.95} & \multirow{5}{*}{0.93} \\
\hline & $\begin{array}{l}\text { I plant trees, flowers, or other plants in my backyard or decorate } \\
\text { my house with short plants. }\end{array}$ & 0.81 & 25.15 & & \\
\hline & I segregate my trashes to biodegradable and non-biodegradable. & 0.91 & 54.81 & & \\
\hline & I collect rainwater or use rain barrels for watering plants, etc. & 0.93 & 93.22 & & \\
\hline & I bring my own shopping bag for shopping. & 0.92 & 68.94 & & \\
\hline \multirow{3}{*}{ Formalism [45] } & $\begin{array}{l}\text { I think that operating procedures established by government } \\
\text { agencies may not necessarily be implemented. }\end{array}$ & 0.99 & 3.37 & \multirow{3}{*}{0.80} & \multirow{3}{*}{0.77} \\
\hline & $\begin{array}{l}\text { In my opinion, many procedures in civil service agencies are only } \\
\text { used as references for implementation. }\end{array}$ & 0.63 & 2.41 & & \\
\hline & $\begin{array}{l}\text { I believe that there is a gap between many of government agencies' } \\
\text { policies and their actual implementation. }\end{array}$ & 0.62 & 2.20 & & \\
\hline \multirow{5}{*}{$\begin{array}{l}\text { Green behavior } \\
\text { intention [49] }\end{array}$} & $\begin{array}{l}\text { After tomorrow, I will try my best to reduce the printing of } \\
\text { unnecessary documents. }\end{array}$ & 0.72 & 16.03 & \multirow{5}{*}{0.95} & \multirow{5}{*}{0.93} \\
\hline & I intend to engage in environmental behavior. & 0.92 & 77.49 & & \\
\hline & Tomorrow, I plan to work in an environmentally friendly way. & 0.94 & 102.98 & & \\
\hline & $\begin{array}{l}\text { Tomorrow, I intend to perform environmentally friendly behaviors } \\
\text { during my work. }\end{array}$ & 0.93 & 97.11 & & \\
\hline & I plan to stop wasting natural resources. & 0.92 & 85.47 & & \\
\hline
\end{tabular}

Note: $\mathrm{GL}$ = green lifestyle; $\mathrm{GB}$ = green behavior; $\mathrm{GBI}$ = green behavior intention; $\mathrm{GA}$ = green attitude; $\mathrm{FOR}$ = formalism; $\mathrm{OES}=$ organization environmental strategy. 


\subsubsection{Descriptive Statistics and Inter-Correlations}

For the purpose of achieving discriminant validity, the square root of AVE from an individual latent variable must be greater than the correlation coefficient between that latent variable and other latent variables in the model [107]. The following table shows the matrix of correlation coefficients between dimensions. The diagonal line is the square root of a dimension's AVE. The square roots of the AVE for each dimension's variables were between 0.76 and 0.91 , which was greater than the correlation coefficient between any two dimensions. This means that the latent variables in the model were indeed different, indicating good discriminant validity of the model. In addition, AVE was also greater than MSV and ASV (see Table 4), which also demonstrates that this study had good discriminative validity [108].

Table 4. Square root of AVE and inter-correlations.

\begin{tabular}{lccccccccc}
\hline & FOR & GA & GB & GBI & GL & OES & ASV & MSV & AVE \\
\hline FOR & $(0.76)$ & 0.11 & 0.12 & 0.00 & 0.05 & 0.03 & 0.01 & 0.02 & 0.58 \\
GA & -0.11 & $(0.87)$ & 0.47 & 0.42 & 0.54 & 0.43 & 0.18 & 0.29 & 0.76 \\
GB & -0.12 & 0.47 & $(0.79)$ & 0.77 & 0.71 & 0.61 & 0.34 & 0.59 & 0.62 \\
GBI & 0.00 & 0.42 & 0.77 & $(0.89)$ & 0.71 & 0.57 & 0.32 & 0.59 & 0.79 \\
GL & 0.05 & 0.54 & 0.71 & 0.71 & $(0.89)$ & 0.55 & 0.32 & 0.50 & 0.79 \\
OES & -0.03 & 0.43 & 0.61 & 0.57 & 0.55 & $(0.91)$ & 0.24 & 0.37 & 0.83 \\
\hline
\end{tabular}

Note: The figures in parentheses indicate the square root of AVE of the study constructs. MSV = maximum share variance; ASV = average share variance. The lower left corner of the diagonal is the correlation coefficient; the upper right corner is the heterotrait-monotrait (HTMT) ratio of correlations. $\mathrm{GL}=$ green lifestyle; $\mathrm{GB}=$ green behavior; $\mathrm{GBI}=$ green behavior intention; $\mathrm{GA}=$ green attitude; $\mathrm{FOR}=$ formalism; OES = organization environmental strategy.

The heterotrait-monotrait (HTMT) ratio of correlations in this study ranged from 0.00 to 0.77 (Table 4 ), and did not exceed 0.85 . These values once again confirm the discriminative validity of this study [109-113].

The matrix below shows the preliminary findings regarding the relationships among research dimensions. Green behavior was positively correlated with green lifestyle, green behavioral intention, green attitude, and organizational environmental strategy. Green behavior was negatively correlated with formalism. The findings regarding the relationships among research dimensions in this study met the theoretical expectations.

\subsection{Model Fit Analysis}

In terms of the absolute fit measure index, the SRMR conceptual model for this study was 0.064 . RMSEA was 0.87 , which was slightly higher than the criterion of 0.05 , but still within the acceptable range. In terms of relative fit measure index, NNFI was 0.97, NFI was 0.96 , CFI was 0.97 , IFI was 0.97 , and RFI was 0.95 . All were greater than the criterion 0.90 , indicating that the hypothetical model is acceptable. In terms of the parsimonious fit measure index, PNFI was 0.86 and PGFI was 0.65 . Both were higher than 0.50. Model AIC was 1451.16, thus meeting requirements as it was smaller than the 0.32 of independence AIC. The above statistical results show the appropriateness of the conceptual models used in this research [107] and that the models were well-matched to the empirical data, which confirms the overall validity of this study.

\section{Results}

This study relied on path coefficient analysis in structural equation modeling (SEM) to test all the hypotheses [114]. The tolerance value of all variables in the regression model was between 0.47 and 1.0, which was higher than 0.1; the VIF value was between 1.0 and 2.14, which was lower than 10. This indicates that the regression model in this paper did not have the problem of multicollinearity.

Green attitude positively affected green behavior, with a statistically significant coefficient of 0.42. Hypothesis 1 was thus confirmed. The finding met the expectation of the 
theory of planned behavior. It was also similar to the results of the study by Yazdanpanah and Forouzani [62], and Shen and Si [65].

The table below shows that green behavioral intention had positive correlations with green behavior. The coefficient was 0.45 , a statistically significant level. Hypothesis $2 \mathrm{a}$ was thus confirmed, with findings similar to those in Bae et al. [72]. The result met the expectation of the theory of planned behavior.

The results of mediation estimates used in this study are shown in Table 5. The direct effect from attitude to intention was $0.23(p<0.01)$, and the mediation percentage was $41.6 \%$; the indirect effect was $0.33(p<0.01)$, and the mediation percentage was $58.4 \%$. The total effect from attitude to intention was $0.56(p<0.01)$, which confirmed that green intention partially mediated the relationship between green attitude and green behavior. According to the above mediation analysis, $\mathrm{H} 2 \mathrm{~b}$ was accepted.

Table 5. Mediation estimates.

\begin{tabular}{|c|c|c|c|c|c|c|c|c|}
\hline \multirow[b]{2}{*}{ Effect } & \multicolumn{8}{|c|}{ 95\% Confidence Interval } \\
\hline & Label & Estimate & SE & Lower & Upper & $\mathbf{Z}$ & $p$ & $\%$ Mediation \\
\hline Indirect & $a \times b$ & 0.33 & 0.04 & 0.25 & 0.41 & 8.23 & $<0.001$ & 58.4 \\
\hline Direct & c & 0.23 & 0.05 & 0.14 & 0.32 & 5.14 & $<0.001$ & 41.6 \\
\hline Total & $c+a \times b$ & 0.56 & 0.05 & 0.46 & 0.66 & 10.91 & $<0.001$ & 100 \\
\hline
\end{tabular}

Note: $\mathrm{a}=$ attitude $\rightarrow$ intention; $\mathrm{b}=$ intention $\rightarrow$ behavior; $\mathrm{c}=$ attitude $\rightarrow$ behavior.

Formalism had a negative impact on green behavior, with a statistically significant coefficient of -0.13 . Hypothesis 3 was thus confirmed. Civil servants with high formalism weigh personal interest greater than public interest. Red tape impedes administrative communication system and command system, making it difficult to implement government agencies' green policies.

Organizational environmental strategy positively affected green behavior. The coefficient was 0.18 , reaching a statistically significant level. Hypothesis 4 was thus confirmed. The finding is similar to the results of the studies by Das et al. [3], Dumont et al. [80], and Norton et al. [82]. An announcement of organizational environmental strategy will be interpreted by civil servants as government agencies' support for and investment in green behavior, which leads to the practice of green behavior.

Finally, green lifestyles have positive correlations with civil servants' green behavior. The coefficient was 0.30 (Table 6 and Figure 2), reaching a statistically significant level. Hypothesis 5 was thus confirmed. The finding is similar to the results of the studies by Han and Lee [91] and Untaru et al. [92], among others. Civil servants' green lifestyles affect their green behavior in the workplace. Environmental protection resources and experience in the family are transferred to government agencies.

Table 6. Path coefficients (coefficients, STDEV, $t$-values).

\begin{tabular}{|c|c|c|c|c|c|}
\hline Hypotheses & Causal Path & Coefficients & $\begin{array}{l}\text { Standard } \\
\text { Deviation }\end{array}$ & $T(Z)$ Statistics & Accept or Reject \\
\hline $\mathrm{H} 1$ & Green attitude $\rightarrow$ green behavior intention & $0.42 * * *$ & 0.05 & 8.56 & accepted \\
\hline $\mathrm{H} 2 \mathrm{a}$ & $\begin{array}{l}\text { Green behavior intention } \rightarrow \text { green } \\
\text { behavior }\end{array}$ & $0.45^{* * *}$ & 0.07 & 6.47 & accepted \\
\hline $\mathrm{H} 2 \mathrm{~b}$ & $\begin{array}{l}\text { Green attitude } \rightarrow \text { green behavior intention } \\
\rightarrow \text { green behavior }\end{array}$ & $0.56^{* * *}$ & 0.05 & 10.98 & accepted \\
\hline H3 & Formalism $\rightarrow$ green behavior & $-0.13^{* *}$ & 0.06 & 2.09 & accepted \\
\hline $\mathrm{H} 4$ & $\begin{array}{l}\text { Organization environmental strategy } \rightarrow \\
\text { green behavior }\end{array}$ & $0.18^{* * *}$ & 0.05 & 3.67 & accepted \\
\hline H5 & Green lifestyle $\rightarrow$ green behavior & $0.30 * * *$ & 0.06 & 5.29 & accepted \\
\hline
\end{tabular}




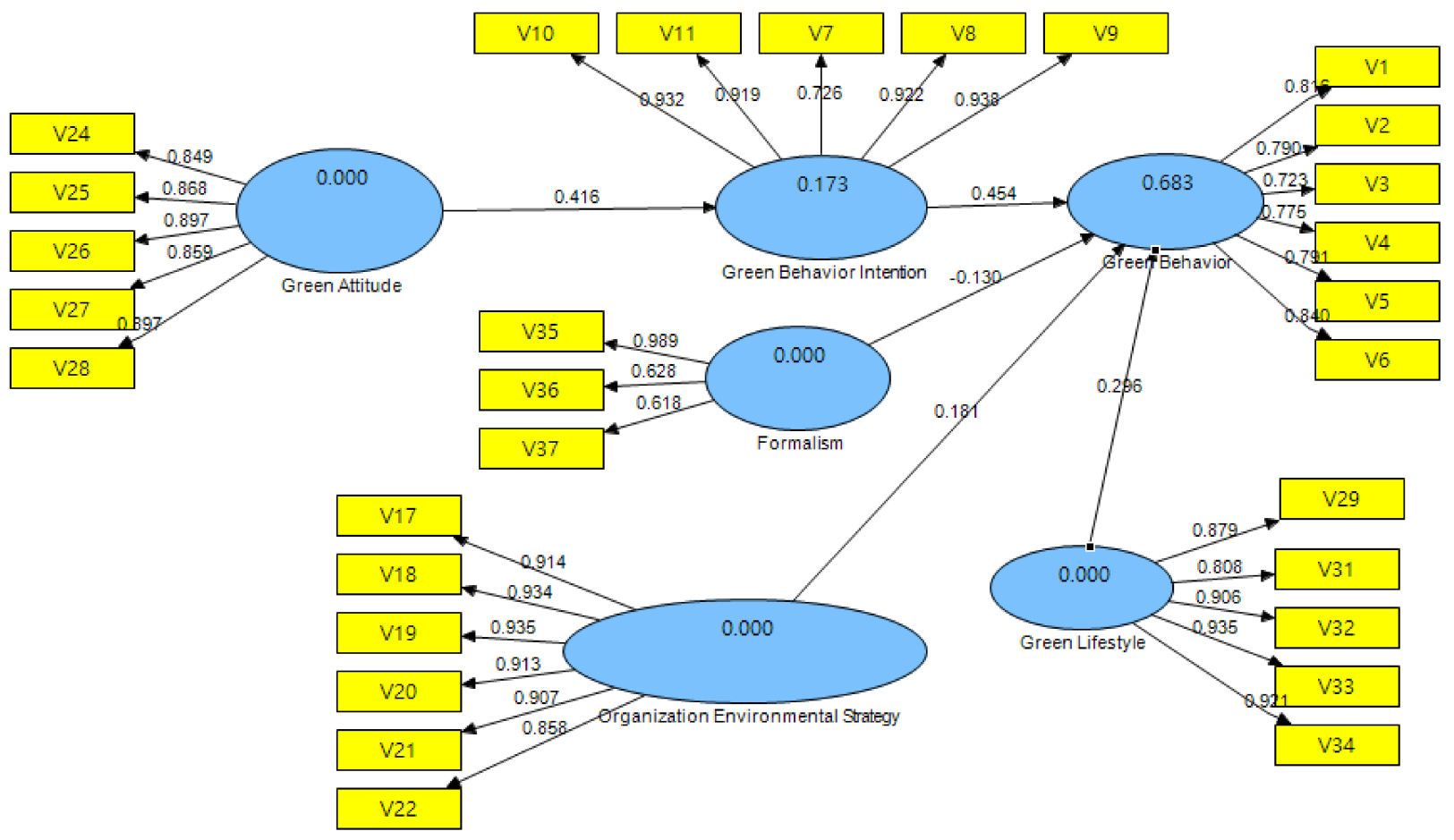

Figure 2. CFA path coefficients.

\section{Discussion}

This research used path coefficient analysis in structural equation modeling (SEM) to test all hypotheses. This study also confirmed that green attitude positively affected green behavioral intention $[8,60-65]$. The result met the expectation of the theory of planned behavior as well $[46,47]$. Green attitudes can be civil servants' personal beliefs and feelings. When civil servants have a positive attitude towards policies and courses of action about organizational environmental sustainability, their green behavioral intentions will increase.

This research confirms that green behavioral intention is the proxy variable for actual behavior itself $[29,35,68,69]$. Civil servants with high green behavioral intention will practice green behavior. The regression coefficient in this regard was close to 0.5 . It also conforms to the expectation of the theory of planned behavior in that behavioral intention is a precursor to actual behavior [49]. For civil servants' green behavior to be improved, it is necessary to first increase their green behavioral intentions. In addition, the mediation analysis of this study also confirmed that green attitude is not only mediated by green intention to green behavior. Green attitude can also directly affect green behavior [115].

What is rather unique about this study is its inclusion of formalism. It was confirmed that formalism negatively affected the green behavior of civil servants. Previous studies seldom used advanced statistics to discuss formalism after Riggs formulated this theory. Although Fox and Joiner apply some statistical techniques [13], their study did not contain inferential statistics for verification. Civil servants with high formalism under paternalist leadership are less willing to implement green behavior and are more indifferent to public interest $[13,14]$. Public agencies primarily perform paperwork and do not faithfully implement policies $[13,14]$. They pay greater attention to ritualistic procedures and ignore green behavior.

This research also confirms that the organizational environmental strategy has positive impact on green behavior $[8,79,80,82,83]$. Government agencies have always been the planners and promoters of green manufacturing, green consumption, green tourism, and green behavioral strategies. The organizational environmental strategies of government agencies also have been announced at the early stage. However, there is not a large amount of research discussing whether these strategies affect civil servants' green behav- 
ior. Most academic research is limited to green design, wasteful consumption, etc. This study confirmed that civil servants' green behavior is also influenced by organizational environmental strategy.

It can be seen from Table 4 of this article that formalism and organizational environmental strategy were negatively correlated, but they did not reach a statistically significant level. During the SEM analysis, it was found that formalism negatively affected green behavior, while organizational environmental strategy positively affected green behavior. In terms of standardization coefficients, the effects of formalism and organizational environmental strategy were similar, but the direction of influence was reversed.

This research also confirmed that the green lifestyle of civil servants had a positive impact on the green behavior of the office. People who practice green life at home can easily bring green behavior to the office $[56,85,86,88-90]$. The promotion of overall green environmental awareness can still increase green behavior in the workplace.

\section{Theoretical and Practical Implications}

The main theoretical contribution of this article is that its findings confirm the theoretical expectation of formalism, Riggs' ecology of administration theory. Formalism indeed is not conducive to the adoption of innovative policies by administrative agencies. Riggs' ecology of administration theory was criticized by a lack of empirical evidence for verification. This article may be an empirical study to preliminarily test formalism. Limited research exists on administrative management, and rarely has research been conducted to analyze the relations between formalism and green behavior. Many Asian countries that have either experienced colonialism or that are currently experiencing social development, as is typical for developing countries, exhibit different degrees of formalism. Even though Taiwan's economy has developed, the human resource management of government agencies is still similar to that of 50 years ago. The appointment, promotion, and assessment of civil servants' performance are not much different from those systems used in the past. It is easy to retain formalism from the past under a system that recruits civil servants through examination and guarantees permanent employment. Research about formalism in Taiwan can also be expanded to developing countries, where formalism is a much more serious problem.

Additionally, this article also confirms the theory of planned behavior, social learning theory, enrichment model, and border theory in public sector. When formalism, organizational environmental strategy, and green lifestyle are linked to green behaviors, the linear relationship between green attitudes, intentions, and behaviors still exists. This study also confirmed that the green intention mediates the relationship between green attitude and green behavior of civil servants. The experience and resources of civil servants' green life will also be transferred and expanded to workplace.

In terms of practical suggestions, the green behavior of civil servants is the same as that of employees of private enterprises. Under the influence of organizational environmental strategy and green lifestyle, the linear relationship between green attitude, green intention, and green behavior still exists. Especially under the negative influence of formalism cognition, the influencing factors of green behavior have not changed much.

In terms of policy recommendations, government agencies need to start setting up environmental protection missions and values within their institutions. The announcement of an agency's mission and values will strengthen green behavioral attitude, green intention, and civil servants' green behavior. It is recommended that government agencies set up a sustainability team to promote recycling program and to assist in the implementation of green procurement. This is to avoid formalism in that civil servants only pretend to comply and green procurement specified in Government Procurement Act is not faithfully implemented. It is also recommended that government agencies go paperless. In recent years, online documents and software have developed at a rapid pace; reductions in printing will lead to decreases in paper use. 
It is important for government agencies to implement energy saving and electricity saving. With the influence of formalism, many organizational environmental protection strategies may not be implemented faithfully. Measures related to environmental protection include improving natural light in the office, switching to LED lights, and cultivating habits of turning off lights and air-conditioning. Other measures include encouraging civil servants to take public transportation to work so as to reduce carbon emissions, as well as using recyclable products, such as eco-friendly cups, to avoid unnecessary waste.

One reason for the formation of formalism includes a lack of evaluation criteria. The criteria include measuring the weight of waste, measuring electricity bill per week, measuring the quantity of paper used per week, and counting green procurement quotas. They will promote green behavior and facilitate the implementation of organizational environmental protection policies. In the future, the use of big data in government agencies should also be considered, as should use of automated lighting and equipment to avoid waste caused by subjective judgement.

From the perspective of waste prevention management, let civil servants know the importance of green attitude and green behavior knowledge. Further planning educational and promotional initiatives allow civil servants to practice green behavior instead of remaining in voluntary green behavior [116-119]. Civil servants can gradually change from voluntary green behavior to compulsive green behavior. Green behavior of civil servants in government agencies should become more frequent. When environmental protection education can change the attitude of civil servants, it can improve the moral motivations, personal responsibility, and self-efficacy of civil servants in practicing green behavior [117]. Education has always been regarded as an effective means of waste prevention.

In addition, civil servants can increase participation in solid waste minimization activities to understand environmental benefits and absorb adequate information [38]. This study also confirmed that green lifestyle positively affects green behavior in civil servants ${ }^{\prime}$ workplaces. Therefore, encouraging civil servants to participate in community waste prevention activities can improve the empowerment and collective action of civil servants' green behavior in the workplace. Functioning inspection and enforcement procedures are also a way to effectively implement waste prevention.

The concept of the circular economy needs to be introduced into government agencies so that civil servants will faithfully engage in green behavior. Finally, government agencies will need to establish an environmental vision and have civil servants devoted to realizing this vision. It is foreseeable that formalism will hinder environmental protection policies and green behavior. It is necessary to establish clear standards for environmentally friendly behavior and to come up with measurements so as to understand the gap between expectations and implementation outcomes. These standards will serve as the basis for green behavior management.

\section{Research Limitations and Future Research Suggestions}

First of all, probability sampling was not used in this article, and thus it is possible that the samples do not represent the population under study, thus leading to sample bias or selection bias. Secondly, previous research has not used a formalism scale; there is not much literature for reference or modification. This limits the number of relevant citations and references. Therefore, this study designed questionnaire items on the basis of the definition of formalism and only one study. Since green behavior intention is a proxy variable of green behavior, the design of items in this study is still somewhat similar. Although the discriminant validity between green behavior intention and green behavior in this study has been passed, future research should still pay attention to the discriminant validity of these two factors.

This research only links formalism, organizational environmental strategy, and green lifestyle to green behavior. According to TPB, formalism, organizational environmental strategy, and green lifestyle may affect green behavior through green behavior intention. This study was limited by the fact that the collected data did not reach statistical significance, 
as well as the fact that the literature review was not very sufficient. Therefore, this study cannot verify the mediating role of green behavior intention. Future research can link the three factors to green attitude or green behavior intention to explore whether there will be different research findings.

Because this research mainly discusses voluntary green behavior, it did not adopt the two factors of subjective norms and performed behavioral control, which will make the theoretical basis of this research relatively insufficient. Future research can adopt all the factors of TPB to make the theoretical basis of the results more sufficient.

This research uses a variety of theoretical models, including prismatic model, theory of planned behavior, social learning theory, enrichment model, spillover model, and border theory. Sometimes the research focus cannot be concentrated, and follow-up research can consider the application of more similar theoretical models.

Due to the limited time available, this study was unable to conduct a longitudinal study. It should be included in future research when there is sufficient time and funding. Finally, in using Taiwan as the main research area, this article may contain cultural bias and stereotypes toward specific phenomena, and thus biases may have affected the research results. It is expected that in future research, the sample size will be expanded, and more places will be added into the analysis in order to achieve generalization of the results.

Funding: This research received no external funding.

Institutional Review Board Statement: Not applicable.

Informed Consent Statement: Not applicable.

Data Availability Statement: The data are available upon request from the author.

Conflicts of Interest: The author declares no conflict of interest.

\section{References}

1. Lu, H.; Liu, X.; Chen, H.; Long, R.; Yue, T. Who contributed to "corporation green" in China? A view of public- and private-sphere pro-environmental behavior among employees. Resour. Conserv. Recycl. 2017, 120, 166-175. [CrossRef]

2. Saleem, M.; Qadeer, F.; Mahmood, F.; Ariza-Montes, A.; Han, H. Ethical leadership and employee green behavior: A multilevel moderated mediation analysis. Sustainability 2020, 12, 3314. [CrossRef]

3. Das, A.K.; Biswas, S.R.; Jilani, M.M.A.K.; Uddin, M.A. Corporate environmental strategy and voluntary environmental behaviorMediating effect of psychological green climate. Sustainability 2019, 11, 3123. [CrossRef]

4. Zhao, J.; Liu, H.; Sun, W. How proactive environmental strategy facilitates environmental reputation: Roles of green human resource management and discretionary slack. Sustainability 2020, 12, 763. [CrossRef]

5. Wijethilake, C. Proactive sustainability strategy and corporate sustainability performance: The mediating effect of sustainability control systems. J. Environ. Manag. 2017, 196, 569-582. [CrossRef] [PubMed]

6. Han, Z.; Wang, Q.; Yan, X. How responsible leadership motivates employees to engage in organizational citizenship behavior for the environment: A double-mediation model. Sustainability 2019, 11, 605. [CrossRef]

7. Kitsios, F.; Kamariotou, M.; Talias, M.A. Corporate sustainability strategies and decision support methods: A biblio- metric analysis. Sustainability 2020, 12, 521. [CrossRef]

8. Norton, T.A.; Parker, S.L.; Zacher, H.; Ashkanasy, N.M. Employee green behavior a theoretical framework, multilevel review, and future research Agenda. Organ. Environ. 2015, 28, 103-125. [CrossRef]

9. Siero, F.; Bakker, A.; Dekker, G.; Van den Burg, M. Changing organizational energy consumption behaviour through comparative feedback. J. Environ. Psychol. 1996, 16, 235-246. [CrossRef]

10. Bissing-Olson, M.J.; Iyer, A.; Fielding, K.S.; Zacher, H. Relationships between daily affect and pro-environmental behavior at work: The moderating role of pro-environmental attitude. J. Organ. Behav. 2012, 34, 156-175. [CrossRef]

11. Environmental Education Law. Available online: https:/ /law.moj.gov.tw /LawClass/LawAll.aspx?pcode=O0120001 (accessed on 23 March 2021).

12. Environmental Protection Policy. Available online: https://www.ey.gov.tw/state/4AC21DC94B8E19A8/bea31948-b13c-4bd7-b1 3b-904a50ee5730 (accessed on 18 March 2021).

13. Fox, G.; Joiner, C. Perceptions of the Vietnamese public administration system. Adm. Sci. Q. 1964, 8, 443. [CrossRef]

14. Milne, R. Mechanistic and organic models of public administration in developing countries. Adm. Sci. Q. 1970, 15, 57. [CrossRef]

15. Tang, C.M.F.; Lam, D. The role of extraversion and agreeableness traits on Gen Y's attitudes and willingness to pay for green hotels. Int. J. Contemp. Hosp. Manag. 2017, 29, 607-623. [CrossRef] 
16. Sihvonen, S.; Partanen, J. Implementing environmental considerations within product development practices: A survey on employees' perspectives. J. Clean. Prod. 2016, 125, 189-203. [CrossRef]

17. Binder, M.; Blankenberg, A.K. Green lifestyles and subjective well-being: More about self- image than actual behavior? J. Econ. Behav. Organ. 2017, 137, 304-323. [CrossRef]

18. Buysse, K.; Verbeke, A. Proactive environmental strategies: A stakeholder management perspective. Strat. Manag. J. 2003, 24, 453-470. [CrossRef]

19. Sharma, M. The role of employees' engagement in the adoption of green supply chain practices as moderated by environment attitude: An empirical study of the Indian automobile industry. Glob. Bus. Rev. 2014, 15, 25-38. [CrossRef]

20. Dyllick, T.; Hockerts, K. Beyond the business case for corporate sustainability. Bus. Strategy Environ. 2002, 11, 130-141. [CrossRef]

21. Wang, Y.F. Modeling predictors of restaurant employees' green behavior: Comparison of six attitude-behavior models. Int. J. Hosp. Manag. 2016, 58, 66-81. [CrossRef]

22. Andersson, L.; Jackson, S.E.; Russell, S.V. Greening organizational behavior: An introduction to the special issue. J. Organ. Behav. 2013, 34, 151-155. [CrossRef]

23. Paillé, P.; Boiral, O. Pro-environmental behavior at work: Construct validity and determinants. J. Environ. Psychol. 2013, 36, 118-128. [CrossRef]

24. Norton, T.A.; Zacher, H.; Ashkanasy, N.M. Organisational sustainability policies and employee green behaviour: The mediating role of work climate perceptions. J. Environ. Psychol. 2014, 38, 49-54. [CrossRef]

25. Kirkwood, J.; Walton, S. How green is green? Ecopreneurs balancing environmental concerns and business goals. Australas. J. Environ. Manag. 2014, 21, 37-51. [CrossRef]

26. Robertson, J.L.; Barling, J. The role of leadership in promoting workplace pro-environmental behaviors. In The Psychology of Green Organizations; Robertson, J.L., Barling, J., Eds.; Oxford University Press: Oxford, UK, 2015; pp. 164-186.

27. Mi, L.; Sun, Y.; Gan, X.; Yang, H.; Lv, T.; Shang, K.; Qiao, Y.; Jiang, Z. Promoting employee green behavior through the person-organization fit: The moderating effect of psychological distance. Front. Psychol 2020, 11, 568385. [CrossRef]

28. Triandis, H.C. Values, attitudes, and interpersonal behavior. In Nebraska Symposium on Motivation; Howe, H., Page, M., Eds.; University of Nebraska Press: Lincoln, NB, USA, 1980; Volume 27, pp. 195-259.

29. Greaves, M.; Zibarras, L.D.; Stride, C. Using the theory of planned behavior to explore environmental behavioral intentions in the workplace. J. Environ. Psychol. 2013, 34, 109-120. [CrossRef]

30. Blok, V.; Wesselink, R.; Studynka, O.; Kemp, R. Encouraging sustainability in the workplace: A survey on the pro-environmental behaviour of university employees. J. Clean. Prod. 2015, 106, 55-67. [CrossRef]

31. Robertson, J.L.; Barling, J. The Psychology of Green Organizations; Oxford University Press: Oxford, UK, 2015.

32. Raub, S.; Liao, H. Doing the right thing without being told: Joint effects of initiative climate and general self-efficacy on employee proactive customer service performance. J. Appl. Psychol. 2012, 97, 651-667. [CrossRef]

33. Parker, S.K.; Wall, T.D.; Jackson, P.R. That's not my job": Developing flexible employee work orientation. Acad. Manag. J. 1997, 40, 899-929. [CrossRef]

34. Tangirala, S.; Ramanujam, R. Exploring nonlinearity in employee voice: The effects of personal control and organizational identification. Acad. Manag. J. 2008, 51, 1189-1203. [CrossRef]

35. Ones, D.S.; Dilchert, S. Environmental sustainability at work: A call to action. Ind. Organ. Psychol. 2012, 5, 444-466. [CrossRef]

36. Luo, Y.; Deng, J. The new environmental paradigm and nature-based tourism motivation. J. Travel Res. 2008, 46, 392-402. [CrossRef]

37. Chan, E.S.; Hon, A.H.; Chan, W.; Okumus, F. What drives employees' intentions to implement green practices in hotels? The role of knowledge, awareness, concern and ecological behavior. Int. J. Hosp. Manag. 2014, 40, 20-28. [CrossRef]

38. McAllister, J. Factors Influencing Solid-Waste Management in The Developing World. Available online: https://digitalcommons. usu.edu/cgi/viewcontent.cgi?article=1537\&context=gradreports (accessed on 3 October 2021).

39. Yukalang, N.; Clarke, B.; Ross, K. Barriers to effective municipal solid waste management in a rapidly urbanizing area in Thailand. Int. J. Environ. Res. Public Health 2017, 14, 1013. [CrossRef]

40. De Groot, J.I.M.; Steg, L. Value orientations to explain beliefs related to environmental significant behavior: How to measure egoistic, altruistic, and biospheric value orientations. Environ. Behav. 2008, 40, 330-354. [CrossRef]

41. Haynes, P.; Fryer, G. Human resources, service quality and performance: A case study. Int. J. Contemp. Hosp. Manag. 2000, 12, 240-248. [CrossRef]

42. Zsoka, A.; Szerenyi, Z.; Szechy, A.; Kocsis, T. Greening due to environmental education? Environmental knowledge, attitudes, consumer behavior and everyday pro-environmental activities of Hungarian high school and university students. J. Clean. Prod. 2013, 48, 126-138. [CrossRef]

43. Zsuzsanna, S.; Zsoka, A.; Szechy, A. Consumer behaviour and lifestyle patterns of Hungarian students with regard to environmental awareness. Soc. Econ. 2011, 33, 89-110.

44. Riggs, F.W. The Ecology of Public Administration; Asia Publishing House: Mumbai, India, 1961.

45. Riggs, F.W. Administration in Developing Countries: The Theory of Prismatic Society; Houghton Mifflin Co: Boston, MA, USA, 1964.

46. Ajzen, I. From intentions to actions: A theory of planned behavior. In Action-Control: From Cognition to Behavior; Kuhl, J., Beckman, J., Eds.; Springer: Berlin/Heidelberg, Germany, 1985. 
47. Ajzen, I. Perceived behavioral control, self-efficacy, locus of control, and the theory of planned behavior. J. Appl. Soc. Psychol. 2002, 32, 665-683. [CrossRef]

48. Bouarar, A.C.; Mouloudj, K. Using the theory of planned behavior to explore employees intentions to implement green practices. Dirassat J. Econ. Issue 2021, 12, 641-659.

49. Ajzen, I. The theory of planned behaviour. Organ. Behav. Hum. Decis. Process 1991, 50, 179-211. [CrossRef]

50. Weiss, H.M. Social learning of work values in organizations. J. Appl. Psychol. 1978, 63, 711-718. [CrossRef]

51. Gibson, S.K. Social learning (cognitive) theory and implications for human resource development. Adv. Dev. Hum. Resour. 2004, 6, 193-210. [CrossRef]

52. Bandura, A. Social learning of moral judgments. J. Personal. Soc. Psychol. 1969, 11, 275-279. [CrossRef] [PubMed]

53. Rothbard, N. Enriching or depleting? The dynamics of engagement in work and family roles-Statistical data included. Adm. Sci. Q. 2001, 46, 655-684. [CrossRef]

54. Barnett, R.C.; Hyde, J.S. Women, men, work, and family. An expansionist theory. Am. Psychol. 2001, 56, 781-796. [CrossRef]

55. Greenhaus, J.H.; Powell, G. When work and family are allies: A theory of work and family enrichment. Acad. Manag. Rev. 2006, 31, 72-92. [CrossRef]

56. Edwards, J.; Rothbard, N. Mechanisms linking work and family: Clarifying the relationship between work and family constructs. Acad. Manag. Rev. 2000, 25, 178-199. [CrossRef]

57. Lambert, S.J. Processes linking work and family: A critical review and research agenda. Hum. Relat. 1990, 43, 239-257. [CrossRef]

58. Clark, S.C. Work, family border theory: A new theory of work, family balance. Hum. Relat. 2000, 53, 747-770. [CrossRef]

59. Fishbein, M.; Ajzen, I. Beliefs, Attitude, Intention and Behavior; Addison-Wesley: Reading, MA, USA, 1975.

60. McIntyre, A.; Milfont, T.L. Who cares? Measuring environmental attitudes. In Research Methods for Environmental Psychology; Gifford, R., Ed.; John Wiley \& Sons, Inc: Hoboken, NJ, USA, 2016; pp. 93-114.

61. Matthies, E.; Selge, S.; Klöckner, C.A. The role of parental behavior for the development of behavior specific environmental norms-The example of recycling and re-use behavior. J. Environ. Psychol. 2012, 32, 277-284. [CrossRef]

62. Yazdanpanah, M.; Forouzani, M. Application of the theory of planned behavior to predict Iranian students' intention to purchase organic food. J. Clean. Prod. 2015, 107, 342-352. [CrossRef]

63. Han, H.; Hwang, J. What motivates delegates' conservation behaviors while attending a convention? J. Travel Tour. Mark. 2017, 34, 82-98. [CrossRef]

64. Zhang, Y.; Wang, Z.; Zhou, G. Determinants of employee electricity saving: The role of social benefits, personal benefits and organizational electricity saving climate. J. Clean. Prod. 2014, 66, 280-287. [CrossRef]

65. Shen, L.; Si, H.; Yu, L.; Si, H. Factors influencing young people's intention toward municipal solid waste sorting. Int. J. Environ. Res. Public Health 2019, 16, 1708. [CrossRef]

66. Steg, L.; Vlek, C. Encouraging pro-environmental behaviour: An integrative review and research agenda. J. Environ. Psychol. 2009, 29, 309-317. [CrossRef]

67. Bosco, F.A.; Aguinis, H.; Singh, K.; Field, J.G.; Pierce, C.A. Correlational effect size benchmarks. J. Appl. Psychol. 2015, 100, 431-449. [CrossRef]

68. Bamberg, S.; Moser, G. Twenty years after Hines, Hungerford, and Tomera: A new meta- analysis of psycho-social determinants of pro-environmental behavior. J. Environ. Psychol. 2007, 27, 14-25. [CrossRef]

69. Holland, R.W.; Aarts, H.; Langendam, D. Breaking and creating habits on the working floor: A field-experiment on the power of implementation intentions. J. Exp. Soc. Psychol. 2006, 42, 776-783. [CrossRef]

70. Locke, E.A.; Latham, G.P. A theory of goal setting and task performance. Acad. Manag. Rev. 1991, 16, 480-483.

71. Chen, C.P.; Lai, C.T. To blow or not to blow the whistle: The effects of potential harm, social pressure and organisational commitment on whistleblowing intention and behavior. Bus. Ethics Eur. Rev. 2014, 23, 327-342. [CrossRef]

72. Bae, T.J.; Qian, S.; Miao, C.; Fiet, J.O. The relationship between entrepreneurship education and entrepreneurial intentions: A meta-analytic review. Entrep. Theory Pract. 2014, 38, 217-254. [CrossRef]

73. Francis, J.J.; Eccles, M.P.; Johnston, M.; Walker, A.; Grimshaw, J.; Foy, R.; Kaner, E.F.S.; Smith, L.; Bonetti, D. Constructing Questionnaires Based on the Theory of Planned Behavior: A Manual for Health Services Researchers; Centre for Health Services Research, University of Newcastle upon Tyne: England, UK, 2004.

74. Park, J.; Ha, S. Understanding pro-environmental behavior: A comparison of sustainable consumers and apathetic consumers. Int. J. Retail Distrib. Manag. 2012, 40, 388-403. [CrossRef]

75. Littleford, C.; Ryley, T.J.; Firth, S.K. Context, control and the spillover of energy use behaviours between office and home settings. J. Environ. Psychol. 2014, 40, 157-166. [CrossRef]

76. Schneider, B.; Ehrhart, M.G.; Macey, W.H. Organizational climate and culture. Annu. Rev. Psychol. 2013, 64, 361-388. [CrossRef] [PubMed]

77. Pye, L.W. Politics, Personality, and Nation Building; Yale University Press: New Haven, CT, USA, 1962.

78. Government Procurement Law. Available online: https:/ /aw.moj.gov.tw $/$ LawClass $/$ LawSingle.aspx?pcode=A0030057\&flno=96 (accessed on 15 March 2021).

79. Ramus, C.A.; Steger, U. The roles of supervisory support behaviors and environmental policy in employee "ecoinitiatives" at leading-edge European companies. Acad. Manag. J. 2000, 43, 605-626. 
80. Dumont, J.; Shen, J.; Deng, X. Effects of green HRM practices on employee workplace green behavior: The role of psychological green climate and employee green values. Hum. Resour. Manag. 2016, 56, 613-627. [CrossRef]

81. Kim, Y.J.; Kim, W.G.; Choi, H.-M.; Phetvaroon, K. The effect of green human resource management on hotel employees' eco-friendly behavior and environmental performance. Int. J. Hosp. Manag. 2019, 76, 83-93. [CrossRef]

82. Norton, T.A.; Zacher, H.; Parker, S.L.; Ashkanasy, N.M. Bridging the gap between green behavioral intentions and employee green behavior: The role of green psychological climate. J. Organ. Behav. 2017, 38, 996-1015. [CrossRef]

83. Zhou, S.; Zhang, D.; Lyu, C.; Zhang, H. Does seeing "mind acts upon mind" affect green psychological climate and green product development performance? The role of matching between green transformational leadership and individual green values. Sustainability 2018, 10, 3206. [CrossRef]

84. Söderholm, P. Environmental Policy and Household Behaviour: Sustainability and Everyday Life; Earthscan: London, UK, 2010.

85. Blackwell, R.; Miniard, P.W.; Engel, J.F. Consumer Behaviour, 10th ed.; Thomson, South-Western: Cincinatti, OH, USA, 2006.

86. Kanter, R.M. Work and Family in the United States: A Critical Review and Agenda for Research and Policy; Russell Sage Foundation: New York, NY, USA, 1977.

87. Han, T.I.; Choi, D. Fashion Brand Love: Application of a cognition-affect-conation model. Soc. Sci. 2019, 8, 256. [CrossRef]

88. Rashid, N.R.N.A.; Wahid, N.A.; Saad, N.M. Employees involvement in EMS, ISO 14001 and its spillover effects in consumer environmentally responsible behaviour. In Proceedings of the International Conference on Environment Proceedings (ICENV 2006), Penang, Malaysia, 13-15 November 2006.

89. Muster, V.; Schrader, U. Green work life balance: A new perspective for green HRM. Ger. J. Res. Hum. Resour. Manag. 2011, 25, 40-156. [CrossRef]

90. Elloy, D.F.; Smith, C.R. Patterns of stress, work-family conflict, role conflict, role ambiguity and overload among dual career couples: An Australian study. Cross Cult. Manag. 2003, 10, 55-66. [CrossRef]

91. Han, H.; Lee, M.J.; Kim, W. Promoting towel reuse behaviour in guests: A water conservation management and environmental policy in the hotel industry. Bus. Strategy Environ. 2018, 27, 1302-1312. [CrossRef]

92. Untaru, E.; Ispas, A.; Candrea, A.N.; Luca, M.; Epuran, G. Predictors of individuals' intention to conserve water in a lodging context: The application of an extended theory of reasoned action. Int. J. Hosp. Manag. 2016, 59, 50-59. [CrossRef]

93. De Roeck, K.; Farooq, O. Corporate social responsibility and ethical leadership: Investigating their interactive effect on employees' socially responsible behavior. J. Bus. Ethics 2017, 151, 923-939. [CrossRef]

94. Su, L.; Swanson, S.R. Perceived corporate social responsibility's impact on the well-being and supportive green behaviors of hotel employees: The mediating role of the employee-corporate relationship. Tour. Manag. 2019, 72, 437-450. [CrossRef]

95. Laroche, M.; Bergeron, J.; Barbaro-Forleo, G. Targeting consumers who are willing to pay more for environmentally friendly products. J. Consum. Mark. 2001, 18, 503-520. [CrossRef]

96. Banerjee, B.; McKeage, K. How green is my value: Exploring the relationship between environmentalism and materialism. In Advances in Consumer Research; Allen, C.T., John, D.R., Eds.; Association for Consumer Research: Provo, UT, USA, 1994; pp. $147-152$.

97. Ragas, S.; Tantay, F.; Chua, L.; Sunio, C. Green lifestyle moderates GHRM's impact on job performance. Int. J. Product. Perform. Manag. 2017, 66, 857-872. [CrossRef]

98. Liu, H.T. Analysis of formalism's moderating effect on the relationships between role stressors and work anxiety-Viewpoints from oriental public administration. Int. J. Inf. Manag. Sci. 2015, 26, 85-101.

99. Nunnally, J.C. Psychometric Theory; McGraw-Hill: New York, NY, USA, 1967.

100. Podsakoff, P.M.; MacKenzie, S.B.; Lee, J.Y.; Podsakoff, N.P. Common method biases in behavioral research: A critical review of the literature and recommended remedies. J. Appl. Psychol. 2003, 88, 879-903. [CrossRef]

101. Murray, J.Y.; Kotabe, M.; Zhou, J.N. Strategic alliance-based sourcing and market performance: Evidence from foreign firms operating in China. J. Int. Bus. Stud. 2005, 36, 187-208. [CrossRef]

102. Lindell, M.K.; Whitney, D.J. Accounting for common method variance in cross-sectional research designs. J. Appl. Psychol. 2001, 86, 114-121. [CrossRef] [PubMed]

103. Wu, T.J.; Yuan, K.S.; Yen, D.C. Leader-member exchange, turnover intention and presenteeism-The moderated mediating effect of perceived organizational support. Curr. Psychol. 2021. [CrossRef]

104. Hair, J.E.; Anderson, R.E.; Tatham, R.L.; Black, W.C. Multivariate Data Analysis; Prentice-Hall: Upper Saddle River, NJ, USA, 1998.

105. Hair, J.F.; Risher, J.J.; Sarstedt, M.; Ringle, C.M. When to use and how to report the results of PLS-SEM. Eur. Bus. Rev. 2019, 31, 2-24. [CrossRef]

106. Fornell, C.R.; Larcker, F.F. Structural equation models with unobservable variables and measurement error. J. Mark. Res. 1981, 18, 39-51. [CrossRef]

107. Hulland, J.S. Use of partial least squares (PLS) in strategic management research: A review of four recent studies. Strateg. Manag. J. 1999, 20, 195-204. [CrossRef]

108. Saleem, M.; Qadeer, F.; Mahmood, F.; Han, H.; Giorgi, G.; Ariza-Montes, A. Inculcation of green behavior in employees: A multilevel moderated mediation approach. Int. J. Environ. Res. Public Health 2021, 18, 331. [CrossRef]

109. Henseler, J.; Ringle, C.M.; Sarstedt, M. A new criterion for assessing discriminant validity in variance-based structural equation modeling. J. Acad. Mark. Sci. 2015, 43, 115-135. [CrossRef] 
110. Voorhees, C.M.; Brady, M.K.; Calantone, R.; Ramirez, E. Discriminant validity testing in marketing: An analysis, causes for concern, and proposed remedies. J. Acad. Mark. Sci. 2016, 44, 119-134. [CrossRef]

111. Naz, S.; Jamshed, S.; Nisar, Q.A.; Nasir, N. Green HRM, psychological green climate and pro-environmental behaviors: An efficacious drive towards environmental performance in China. Curr. Psychol. 2021. [CrossRef]

112. Ying, M.; Faraz, N.A.; Ahmed, F.; Raza, A. How does servant leadership foster employees' voluntary green behavior? A sequential mediation model. Int. J. Environ. Res. Public Health 2020, 17, 1792. [CrossRef]

113. Moon, S.J. Investigating beliefs, attitudes, and intentions regarding green restaurant patronage: An application of the extended theory of planned behavior with moderating effects of gender and age. Int. J. Hosp. Manag. 2021, 92, 102727. [CrossRef]

114. Jöreskog, K.G.; Söbom, D. LISREL 8: Structural Equation Modeling with the SIMPLIS Command Language; Scientific Software International: Chicago, IL, USA, 1993.

115. Tian, H.; Zhang, J.; Li, J. The relationship between pro-environmental attitude and employee green behavior: The role of motivational states and green work climate perceptions. Environ. Sci. Pollut. Res. 2020, 27, 7341-7352. [CrossRef]

116. Zorpas, A.; Lasaridi, K.; Abeliotis, C.; Voukkali, I.; Loizia, P.; Georgiou, A.; Chroni, C.; Phanou, K.; Bikaki, N. Waste prevention campaign regarding the waste framework directive. Fresenius Environ. Bull. 2014, 23, 2876-2883.

117. Zorpas, A.A.; Lasaridi, K.; Voukkali, I.; Loizia, P.; Chroni, C. Promoting sustainable waste prevention strategy activities and planning in relation to the waste framework directive in insular communities. Environ. Process 2015, 2, 159-173. [CrossRef]

118. Zorpas, A.A.; Voukkali, I.; Loizia, P. Effectiveness of waste prevention program in primary students' schools. Environ. Sci. Pollut. Res. 2017, 24, 14304-14311. [CrossRef]

119. Zorpas, A.A.; Dimitriou, M.; Voukkali, I. Disposal of household pharmaceuticals in insular communities: Social attitude, behaviour evaluation and prevention activities. Environ Sci. Pollut. Res. Int. 2018, 25, 26725-26735. [CrossRef] 